\title{
ESTIMATION OF WILLINGNESS TO PAY TOWARDS RIVERSIDE LANDSCAPE DESIGN
}

\author{
Atrida Hadianti*, Yoshiaki Kubota** \\ *)Department of Architecture and Planning Faculty of Engineering, \\ Universitas Gadjah Mada, Indonesia \\ **) Graduate School of Science and Engineering for Research, Life, \\ Information and System Sciences, Human and Life Information Systems, \\ University of Toyama, Japan \\ e-mail: atridahadianti@gmail.com
}

\begin{abstract}
Riverside landscape design is developed not only to enhance amenity but also to address disaster risks. This study aims to estimate the value of the design of the riverside landscape, in terms of amenity and disaster mitigation. Contingent valuation method (CVM) is used for the valuation of the proposed design of the riverside landscape. The case study was taken place in Yogyakarta City, Indonesia, that has three main rivers flowing through the city; Winongo River, Code River, and Gajahwong River. As the rivers are headed from Merapi volcano, the community that occupied the riverside areas is threatened by the risks of cold pyroclastic debris flow, besides the regular riverine flood. Respondents are family representatives that chosen randomly from the total population of Yogyakarta City. There are 580 samples, consists of 333 samples of Type A and 247 samples of Type B. Visual image with an explanation of amenity obtained higher WTP rather than with explanation of disaster mitigation indicates that the explanation of amenity features of the design is valued higher rather than disaster mitigation features. In addition, the value of extrapolated WTP results in a considerable amount in a monetary term that represents the cost of realization of the design and also serves as the feasibility of the project. However, the visual image contains a mixed value of the design to some extends, and the explanation increases the value of the design, due to the respondents may grasp other aspects than explained by viewing the visual image of the design. Reasons for willing to pay are all positively related to $W T P$, implies that people behave towards the riverside area is influencing the value, specifically related to their financial state. CVM as a valuation technique for the public good can be used to understand the perception and also to measure the acceptance of the public towards the proposed design.
\end{abstract}

Keywords: landscape design, contingent valuation method, willingness to pay, amenity, disaster mitigation 


\section{INTRODUCTION}

Riverside area serves as a buffer zone between land and water, where the ecological ecosystem formed and interacts. Its natural function becomes the habitat for plants, soil, water, microbes, and people. Furthermore, the natural ecosystem help to control floods and erosion, purify water and recharge groundwater supplies, moreover they also offer recreational and aesthetic value (Gardiner and Cole, 1991). Planning for the Riverside area in urban context need to be comprehensive, in order to reconcile economic and environmental objectives, and furthermore, to ensure sustainability (Gardiner et al., 1993).

Cities and town are typically built in the area around the streams and rivers. In fact, many cities in South East Asian countries are in floodplains of major rivers in which urban sprawl has grown fast following the growth of development. In Jakarta City, most of the areas covered by concretes and it concentrated in the city center (Joga and Ismaun, 2011), with 13 rivers flowing through the city and half of the riverside areas are utilized for settlement in a disturbed condition (Waryono, 2002). Degradation of environmental quality is not the only problem encountered by the riverside area, the dense settlement put this area exposed to disaster risk, mainly flooding. Floods are the most costly natural disaster that its frequency, extent and subsequent hazard affected by settlement patterns and the development of land and infrastructures (Blaikie et al., 1994).

There are three rivers that headed from Merapi volcano, which flows through Yogyakarta City; Winongo River, Code River, and Gajahwong River. The risk of cold pyroclastic debris flow is mainly threatened residents who live along the riverside because it could flood the neighborhoods and destroyed houses. Unfortunately, the community that resides the areas is mostly low-income, a condition that increases their vulnerability towards the risk of flood and debris flow. Therefore, redevelopment of the riverside area is strongly needed to protecting the community from disasters and to enhancing a good environmental quality in where they live

Several attempts to redevelop the riverside area, particularly in Yogyakarta City, were carried out concerning the aspects of ecology (Maryono, 2005), sustainability (Soemardiono and Gusma, 2014) and housing (Bawono and Astuti, 2011). In addition, the disaster mitigation strategies through community-based monitoring and early warning system have been introduced (Fathani and Legono, 2012), also the application of local embankment (Setiawan, 2002) and recommended a width of the flood plain to increase river capacity (Sulistiono, 2011). By considering experiences and recommendations from previous researches, this study is attempted to propose a concept of riverside landscape design that integrates amenity and disaster mitigation. The design does not only enhance the amenity aspect but also the function aspect, in which the improvement of aesthetic and enjoyment is complemented with disaster mitigation function.

Redevelopment of a public facility requires integrating public participation into the process. However, people's willingness to participate in the redevelopment process is relying on their interest in the project, which is related to the value of the public facility. As a public good, valuation of the public facility is needed, since 
people do not purchase for public goods directly. Like most traded goods, the valuation of the goods is not only influenced by the mere impression, but also because of the individual's knowledge of the goods. Information is necessary to provide knowledge to the user about the goods.

The objective of this study is to estimate the value of the design of the Riverside area, in terms of amenity and disaster mitigation. To meet the objective, contingent valuation method (CVM) is used for the valuation of the proposed design of the Riverside area. The value of impression towards the proposed design is converted into the value of money. This concept refers to the amount that people willing to pay to get the merits of specific services or willingness to endure welfare loss from a reduced provision of services (Mitchell and Carson, 1989; Garrod et al., 1996).

In this study, a conceptual design is generated to be evaluated in two separated values; amenity and disaster mitigation. Through the CVM test, estimated willingness to pay is obtained. Estimated WTP for design with amenity explanation gained more value than the one with an explanation of disaster mitigation. WTP estimation results in a considerable amount in the monetary term that reflects the importance of the proposed project, in this case, is the redevelopment of the riverside landscape, which can serve as a feasibility study. Factors influencing the willingness to pay are also identified through the bivariate test. Affordability, education, and distance to river area are positively related to WTP, whereas the living duration and experience to flood disaster expressed whereas the living duration and experience to flood disaster expressed a negative correlation.

\section{THEORY / RESEARCH METHODS}

Value of the development of the riverside area is depending on the viewpoint, in which use value includes the increasing land price, decreasing flood damages, compensation for relocation, and in the other hand, non-use value includes among others aesthetic, recreation and preservation of the natural habitat. This research is attempted to estimate the non-market value of landscape design in Riverside area, therefore the contingent valuation method (CVM) is chosen for this research because of its ability to calculate both use value and non-use value. In order to measure the value of the riverside landscape design, there are given situations: the existing conditions with no improvements (considered as 'without-case') (Figure 1) and proposed design with improvements (considered as 'with-case') (Figure 2) presented as a hypothetical scenario.

The scenario in this study developed from an explanation of the existing condition, which leads to negative effects, then the importance of redevelopment by applying the proposed design. Information about the design provided in image and explanation. The explanation is divided into 2 (two) aspects, namely amenity and function. Amenity aspect consists of an aesthetic and recreational feature of the design. Meanwhile, the function aspect focuses on disaster mitigation feature, that is to protect the riverside area from risk of flooding. 

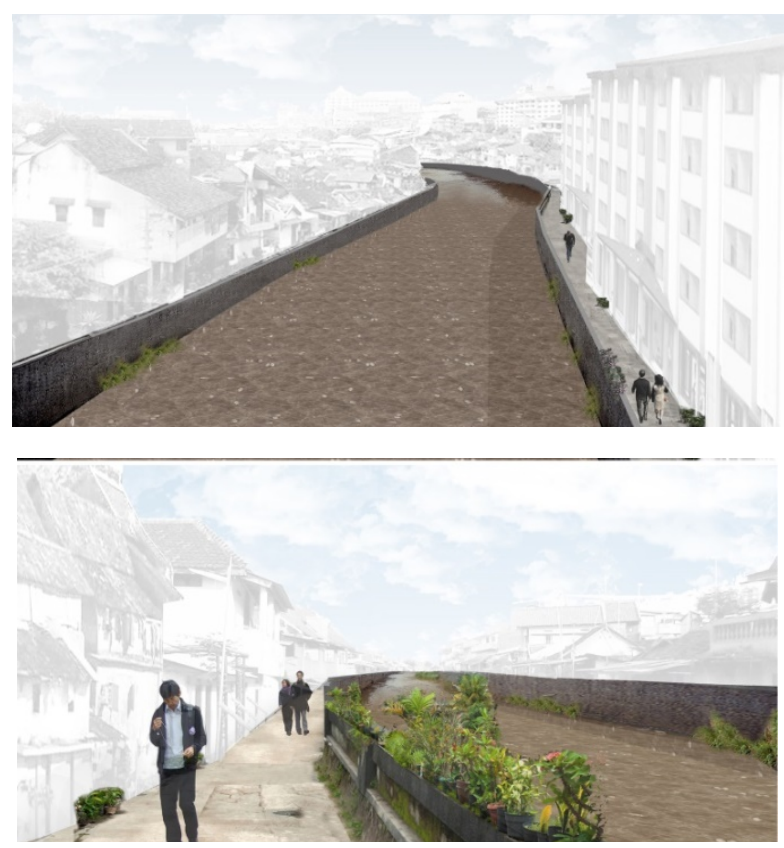

Figure 1. The visual image of without-case (existing condition) Source: author, 2015
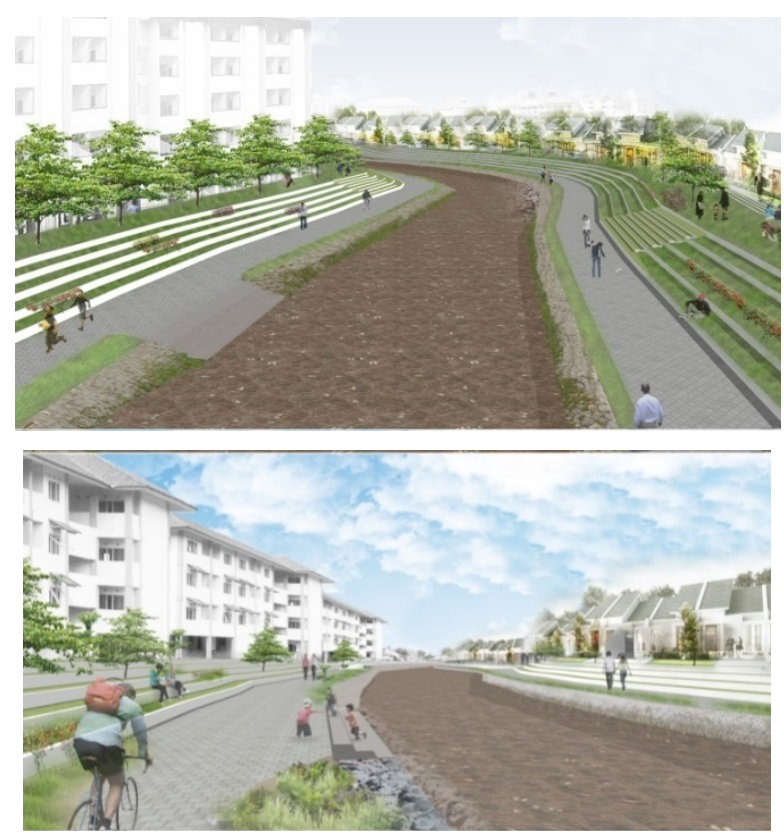

Figure 2. The visual image of with-case (design) Source: author, 2015 


\section{Survey Design}

This study is using questionnaire, in which there are two types of the questionnaire tested in this study, namely Type A and Type B. Type A explained the amenity features, whilst Type B explained disaster mitigation features of the landscape design. The visual image of the design for both valuations are identical, however, the explanation is different in order to evaluate the value of amenity and disaster mitigation distinctively. Afterward, the respondent is asked for their willingness to pay for the improved landscape (with-case) compared to the existing condition (without-case). The estimated amount of payment for the public good is considered as the value possessed by the landscape design or improvement of the landscape.

\section{Elicitation Method}

Elicitation method used in this study is double-bounded dichotomous-choice (DBDC) in purpose to achieve statistical efficiency as additional information can be elicited (Bateman et al., 1999). DBDC elicitation method asked the closed-ended question of the bid amount chosen randomly then followed by the question if they would pay a higher or lower amount considering the first bid (Figure 3). By using DBDC, statistical efficiency can be achieved as additional information can be elicited regardless of the problem in the follow-up bid that influenced by the first bid (Bateman et al., 1999).

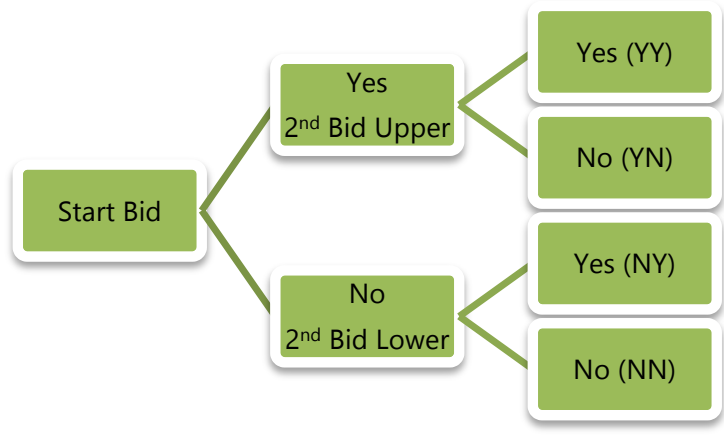

Figure 3. Application of DBDC elicitation method Source: analysis, 2016

\section{Bid Values}

Bid amount for start bid (Table 1) used in valuation is offered randomly, the amount is determined from the result of pre-test that conducted prior to the field survey. Questionnaire sheet is prepared with certain bid amount that chosen randomly by the interviewer regardless of the respondent's profile. Payment vehicle used in this study is an additional tax that refers to the tax of land and building (L\&B) and income tax. Duration of the payment is during the respondent's occupancy in Yogyakarta City. 
Table 1. Bid values

\begin{tabular}{ccc}
\hline \multirow{2}{*}{$1^{\text {st bid }}$} & \multicolumn{2}{c}{ 2 $^{\text {nd }}$ bid } \\
\cline { 2 - 3 } & $\begin{array}{c}\text { Yes } \\
\text { (Higher) }\end{array}$ & $\begin{array}{c}\text { No } \\
\text { (Lower) }\end{array}$ \\
\hline 1000 & 2000 & 500 \\
2000 & 5000 & 1000 \\
5000 & 10000 & 2000 \\
10000 & 20000 & 5000 \\
20000 & 30000 & 10000 \\
\hline \multicolumn{3}{c}{}
\end{tabular}

\section{Data Collection}

A pre-test is conducted prior to the questionnaire survey in the field. The pre-test is done in purpose to test the questionnaire (Arrow et al., 1993); to evaluate whether the questionnaire is understandable or not, identify potential bias occurrence and determine bidding price for willingness to pay (WTP). Question of willingness to pay is asked in an open-ended question, "How much you willing to pay for the development of riverside in 3 (three) rivers in Yogyakarta City as additional tax?". Result of WTP from the pre-test survey is then used to determine the bid-value for WTP in the real questionnaire.

Data collection conducted by face-to-face interview with family representatives that chosen randomly from the total population of Yogyakarta City. The total number of the sample acquired is 580 samples, consists of 333 samples of Type A and 247 samples of Type B. Questionnaire sheet became a guideline in conducting the interviews. Survey assistant conducted the interview according to the questions in the questionnaire and explain the scenario that is written in the questionnaire sheet. Design images are printed in a separate booklet to show clearer images to the respondents. A face-to-face interview was chosen rather than a phone interview or mail in purpose to help the respondent understand the scenario and questions more clearly.

\section{Data Analysis}

The WTP method in this study is analyzed through descriptive, extrapolation and graphics comparison. Descriptive analysis was done to determine WTP value of each type of questionnaire (Type A and Type B) by using software Excel-based CVM (Version 4.0; Kuriyama, 2011). Extrapolation is calculated in order to estimate the WTP value on a larger scale, in which WTP value (mean and median) is multiplied by a total number of household and twelve months. Graphics comparison is used to analyze the result of WTP by comparing the bar chart of WTP derived from descriptive analysis. Value of Amenity and Function aspect of the riverside landscape design in the valuation is determined through analyzing the gap between graphs of mean WTP. In addition, the graph of median WTP is used to confirm the analysis by comparing to the graph of mean WTP. Furthermore, socio-demographic 
and attitudinal variables are analyzed through bivariate analysis to find the WTP determinants.

\section{RESULT AND DISCUSSION}

Table 1 shows the estimation of willingness to pay towards the riverside landscape design in Yogyakarta City obtained from the CVM test. Type A, with the explanation of amenity, achieved higher value than Type B the explanation of disaster mitigation. There is a difference between Type A and Type B (Figure 4) in the amount of IDR 604 (mean WTP) and IDR 119 (median WTP) that represents the value of the amenity with an explanation. The difference between the result of Type A and Type B shows that the respondent is valuing higher on the explanation of amenity features of the design rather than disaster mitigation features.

Respondents may grasp other aspects than explained by viewing the visual image of the design. People may answer the value with consideration other than the certain aspect of the design that explained. It is implied that without any explanation, they value the design to some extents. In addition, with more specific information regarding the design provided, the value is increased. Besides the mixed values, there are several biases also occurred, namely starting point bias (Brookshire et al. 1976), budget constraint (Fujita, 2005) and information bias (Ajzen et al, 1996).

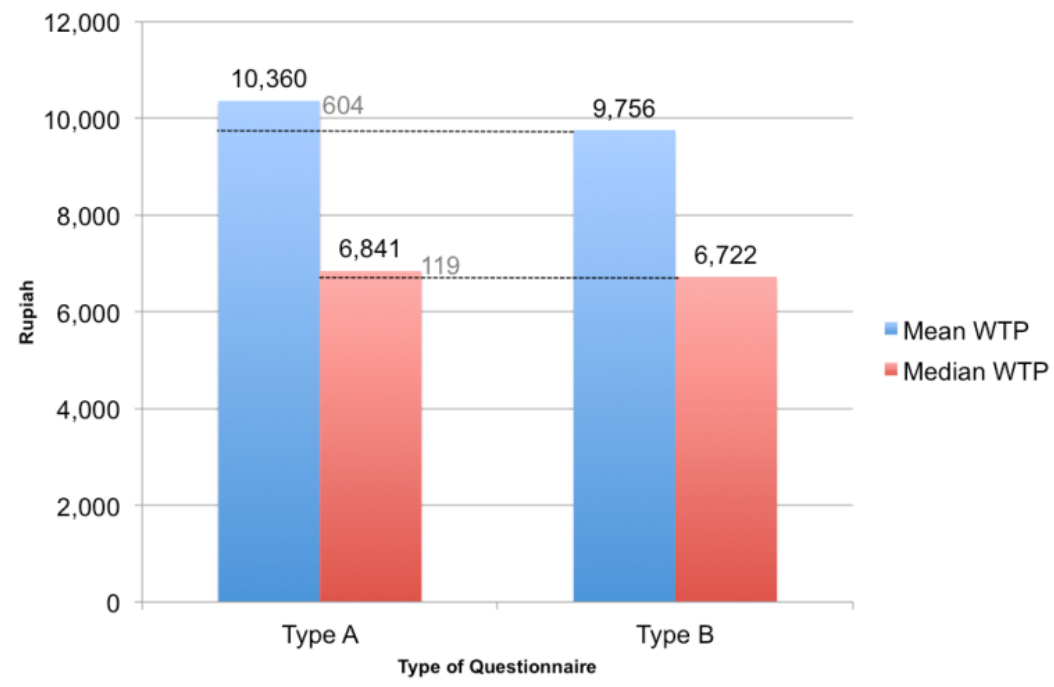

Figure 4. Comparison of estimated WTP

Source: analysis, 2016

The value of extrapolated WTP was calculated by multiplying mean WTP by twelve months by a total number of household in Yogyakarta City (Table 2). The value of extrapolated WTP represents the cost of realization of the design, also serves as the feasibility of the project (Ahmed and Gotoh, 2006). 
Table 2. Willingness to pay

\begin{tabular}{lcc}
\hline & Type A & Type B \\
\hline Mean WTP (IDR) & 10,360 & 9,756 \\
Median WTP (IDR) & 6,841 & 6,722 \\
Total number of household & 132,550 & 132,550 \\
Extrapolated WTP (IDR) & $16,478,616,000$ & $15,517,893,600$ \\
Likelihood & -0.318 & -0.542 \\
$\mathrm{p}$ & 0.018 & 0 \\
$\mathrm{R}$ & 0.498 & 0.392 \\
Sample & 333 & 247 \\
\hline & &
\end{tabular}

In purpose to identify factors influencing willingness to pay, this study performs bivariate analysis towards reasons of WTP response, socio-demographic variables and attitudinal variables. Reasons for WTP response resulted in a similar pattern in which Type B shows a higher correlation to WTP than Type A (Table 3). Type B significantly has a higher correlation to WTP in Responsibility than Type A, indicating that the explanation of disaster mitigation make the respondents feel it is the responsibility for the people living in Yogyakarta City to pay for improving the landscape. Meanwhile, Type A resulted in higher correlation than Type B regarding economic and tourism value showing that the explanation of amenity increase the value of the design and it is influenced by the consideration of economic and tourism value.

Analyses of WTP determinant also consider the respondents' sociodemographic background as well as the attitude of the respondents (Table 3). WTP is positively related to education and income, which in line with the findings of previous researches (del Saz Salazar and García Menéndez, 2007; Yang et al, 2008, Yoo and Kwak, 2009). Education level influences the value of a riverside design due to their reference to the ideal state of a riverside area. While the relationship with income means that valuation is influenced by consideration of ability to pay. Remarkably, distance to the river is positively related to WTP, this result is contrary to the conventional relationship between distance and WTP in CV studies (Pate and Loomis, 1997; Fujita 2005). In this study, WTP is increased as we go further from the river. This indicated that the people living closer to the river are less likely willing to pay than those who live further. This obviously related to the economic condition of people who live close to the river, which is mostly low-income, or even more astonishing that the project may affect the existence of their house. Higher WTP gained from people living far from the Riverside shows that the redevelopment of the Riverside area is strongly demanded and more suggested by the broader community, not solely from the perspective of Riverside residents. 
Table 3. WTP determinants (Pearson Correlation)

\begin{tabular}{|c|c|c|c|}
\hline Factor & & Type A & Type B \\
\hline \multirow[t]{10}{*}{ Reason of WTP response } & Preference & $.185 * *$ & $.240^{* *}$ \\
\hline & $\begin{array}{l}\text { Importance to improve } \\
\text { riverside area }\end{array}$ & $.282 * *$ & $.349 * *$ \\
\hline & $\begin{array}{l}\text { Importance to use additional } \\
\text { tax }\end{array}$ & $.275^{* *}$ & $.353^{* *}$ \\
\hline & Affordability & $.286^{* *}$ & $.360 * *$ \\
\hline & Responsibility & $.170 * *$ & $.363 * *$ \\
\hline & Suitability & $.161 * *$ & $.178 * *$ \\
\hline & Economic and tourism value & $.218 * *$ & $.171 * *$ \\
\hline & Natural and cultural value & $.197 * *$ & $.191 * *$ \\
\hline & Inheritance value & $.203 * *$ & $.260 * *$ \\
\hline & Preference & $.185 * *$ & $.240 * *$ \\
\hline \multirow[t]{7}{*}{ Socio-demographic } & Age & -0.024 & -0.077 \\
\hline & Education & $.167 * *$ & 0.04 \\
\hline & Income & $.177^{* *}$ & $.170^{* *}$ \\
\hline & Household size & -0.025 & 0.049 \\
\hline & $\begin{array}{l}\text { Income person in the } \\
\text { household }\end{array}$ & 0.006 & -0.003 \\
\hline & House ownership & -0.094 & 0.038 \\
\hline & Living duration & $-.131 *$ & 0.004 \\
\hline \multirow[t]{4}{*}{ Attitudinal } & Distance to river & $.180 * *$ & 0.054 \\
\hline & Frequency of visit & -0.034 & -0.056 \\
\hline & Flood experience & -0.087 & $-.141^{*}$ \\
\hline & Flood estimation & -0.003 & $-.123 *$ \\
\hline
\end{tabular}

** Correlation is significant at the 0.01 level (2-tailed).

* Correlation is significant at the 0.05 level (2-tailed).

Source: analysis, 2016

\section{CONCLUSIONS}

WTP estimation results in a considerable amount in the monetary term that reflects the importance of the proposed project as it is indicated the economic benefits of the redevelopment of the riverside landscape. Policymaker should consider the result of a CVM study, especially for pricing decision. Values clarified from CVM study can be considered a feasibility study to observe the public acceptance towards the proposed design or plan. However, the value could not be used to determine tax or price since it is just a reflection of the intangible benefit of the development, not include the actual cost of the project.

Reasons for willing to pay are all positively related to WTP, the reason of importance to improve the riverside area, important to use additional tax, 
affordability and responsibility are strongly correlated comparing with the other reasons. Thus, it is indicated that people behave towards the riverside area is influencing the value, specifically related to their financial state. This indication is interconnected with the socio-demographic and attitudinal background. WTP determinant should not only analyze the direct correlation between the variables to WTP. It is important to analyze the causal relationship between variables to understand deeper consideration from multiple perspectives. Therefore, the comprehensive understanding of the issue can be covered, and then the core problems can be addressed.

CVM as a valuation technique for the public good can be used to understand the perception and also to measure the acceptance of the public towards the proposed design. However, in order to examine the value of amenity and disaster mitigation, CVM test cannot distinguish the value of each aspect. Explanation of the amenity aspect obtained higher than disaster mitigation aspect, indicating that the amenity carries more economic benefit. The visual image of the design contains mixed values implicitly, that in turn will influence the value of the proposed design to some extents. The additional information may increase the value of the design but needs to clarify with explanation and without explanation separately.

\section{REFERENCES}

Ahmed, S.U. and Gotoh, K. (2006) Cost-Benefit Analysis of Environmental Goods by Applying the Contingent Valuation Method, Springer-Verlag, Tokyo.

Ajzen, I., Brown, T. C., Rosenthal, L. H. (1996) Information Bias in Contingent Valuation: Effects of Personal Relevance, Quality of Information, and Motivational Orientation, Journal of Environmental Economics and Management, 30(1), 43-57, Elsevier Inc., United States.

Arrow, K., Solow, R., Portney, P.R., Leamer, E.E., Radner, R., Schuman, H., (1993) Report of the NOAA panel on contingent valuation (Fed. Regist. 48), National Oceanic and Atmospheric Administration, United States.

Bateman, I.J., Langford, I.H., Rasbash, J. (1999) Willingness-to-pay question format effects in contingent valuation studies. In Bateman IJ, Willis KG[eds], Valuing environmental preferences. Oxford University Press, Oxford.

Bawono, S. E. and Astuti, Z. B. (2011) The Capacity of Flat Rental to Transform Future Kampong Code, Yogyakarta , Indonesia, Paper/Proceeding for FIG Working Week 2011 Bridging, 1-15, 18-22 May 2011, Marrakech, Morocco.

Blaikie, P., Cannon, T., Davis, I., Wisner, B. (1994) At risk: natural hazards, people's vulnerability, and disasters, Routledge, London.

Brookshire, D. S., Ives, B. C., Schulze, W. D. (1976) The valuation of aesthetic preferences. Journal of Environmental Economics and Management, 3(1), 325-346, Elsevier Inc., United States. 
del Saz Salazar, S. and García Menéndez, L. (2007), Estimating the non-market benefits of an urban park: Does proximity matter?, Land Use Policy, 24(1), 296-305, Elsevier BV, Netherlands.

Fathani, T. F. and Legono, D. (2012) The Application of Monitoring and Early Warning System of Rainfall-Triggered Debris Flow at Merapi Volcano , Central Java , Indonesia, In Wang, F. et al. [eds], Progress of Geo-Disaster Mitigation Technology in Asia, Springer-Verlag Berlin Heidelberg, New York.

Fujita, Y. (2005) Estimation of Willingness-to-Pay (WTP) for Water and Sanitation Services through Contingent Valuation Method ( CVM ) A Case Study in Iquitos City, The Republic of Peru (JBICI Review No.11 March 2005), Japan Bank for International Cooperation, Japan.

Gardiner, J.L., Cole, L. (1991) Catchment Planning: The way forward for rive protection. In Boon, P.(ed.), Paper/Proceeding for International Conference on the Conservation and Management of Rivers, English Nature, York.

Gardiner, J.L., Edwards, P.J., Ball, J.H. (1993) Urban waterside: context and sustainability. In White, K. N. [eds], Urban Waterside Regeneration: problems and prospects, Ellis Horwood Limited, England.

Garrod, G D, Willis, K G, Bjarnadottir, H and Cockbain, P. (1996) The non-priced benefits of renovating historic buildings: a case study of Newcastle's Grainger Tower, Cities, 13(1), 423-430, Elsevier Ltd., United Kingdom.

Joga, N., and Ismaun, I. (2011) RTH 30\%! Resolution of the Green (City), Gramedia Pustaka Utama, Jakarta.

Kuriyama, K. (2011) ExcelでできるCVM (Version 4.0) [Software]. Available from http://kkuri.eco.coocan.jp/research/introtxt/index.html.

Maryono, A. (2005), Ecological Hydraulics of River Development (2nd Edition), Postgraduate Study UGM, Yogyakarta.

Mitchell, R.C., \& Carson, R.T. (1989) Using surveys to value public goods: The contingent valuation method, Resources for the Future Publié par, Washington D.C., USA.

Pate, J., \& Loomis, J. (1997) The effect of distance on willingness to pay values: A case study of wetlands and salmon in California. Ecological Economics, 20(1), 199-207, Elsevier BV, Netherlands.

del Saz Salazar, S. and García Menéndez, L. (2007) Estimating the non-market benefits of an urban park: Does proximity matter? Land Use Policy, 24(1), 296-305, Elsevier BV, Netherlands.

Setiawan, B. (2002). Integrating Environmental Goals into Urban Redevelopment Schemes: Lessons from the Code River, Yogyakarta, Manusia dan Lingkungan, 6(16), 55-63, Pusat Studi Lingkungan Hidup UGM, Yogyakarta.

Soemardiono, B. and Gusma, A. F. (2014) The Development of Code River Area in Yogyakarta as a Sustainable Urban Landscape Asset acknowledging Local Traditional Knowledge, International review for spatial planning and sustainable development, 2(4), 4-18, SPSD Press, Kanazawa. 
Sulistiono, B. (2011) Prediksi tinggi genangan banjir kali code di kota yogyakarta pasca erupsi merapi tahun 2010. Paper/Proceeding for Seminar Nasional: Pengembangan Kawasan Merapi : Aspek Kebencanaan dan Pengembangan Masyarakat Pasca Bencana, 89-102, DPPM\& MTS UII, Yogyakarta.

Yang, W., Chang, J., Xu, B., Peng, C., Ge, Y. (2008) Ecosystem service value assessment for constructed wetlands: A case study in Hangzhou, China. Ecological Economics, 68(1), 116-125, Elsevier BV, Netherlands.

Yoo, S.H., Kwak, S.Y. (2009) Willingness to pay for green electricity in Korea: a contingent valuation study. Energy Policy, 37(12), 5408-5416, Elsevier Ltd., United Kingdom. 